\title{
PENGARUH PERSEN HASIL PEMBAKARAN SERBUK KAYU DAN AMPAS TEBU PADA MORTAR TERHADAP SIFAT MEKANIK DAN SIFAT FISISNYA
}

\author{
Dahyunir Dahlan, Sri Mulyati \\ Laboratorium Fisika Material - Jurusan Fisika, FMIPA UNAND \\ Email: dahyunir@yahoo.com
}

\begin{abstract}
ABSTRAK
Telah dilakukan penelitian tentang pengaruh persen massa pembakaran serbuk kayu dan ampas tebu terhadap sifat mekanik dan fisis mortar. Bahan dicampur dengan komposisi $0 \%, 5 \%, 10 \%$, $15 \%, 20 \%$ dan $25 \%$ massa dari kedua jenis bahan tersebut. Hasil yang didapatkan menunjukkan bahwa terjadi peningkatan kuat tekan, kuat tarik dan densitas apabila campuran ditambahkan hingga 15\% massa, kemudian menurun kembali seiring penambahan konsentrasi pembakaran serbuk kayu dan ampas tebu. Nilai optimum sifat mekanis didapatkan pada konsentasri optimal, bagi pembakaran serbuk kayu adalah $15 \%$ massa sementara bagi pembakaran ampas tebu adalah $10 \%$ massa.
\end{abstract}

Kata kunci: mortar, serbuk kayu, ampas tebu, kuat tekan, densitas

\section{PENDAHULUAN}

Kebutuhan perumahan, perhubungan dan industri berdampak pada peningkatan kebutuhan bahan-bahan pendukungnya. Salah satu yang meningkat tajam adalah kebutuhan terhadap produk mortar. Mortar disebut juga plesteran. Mortar dibuat dengan menggunakan pasir dan semen. Dalam pembuatan mortar harus mempunyai sifat fisis dan mekanis sesuai dengan standar, misalnya ASTM ( American Society for Testing and Materials ). Meskipun teknologi mortar telah terbukti kemampuannya, namun karena tuntutan konstruksi terhadap kekuatan, kelenturan dan keawetan maka teknologi ini dapat ditingkatkan efektifitas kinerjanya dengan pendekatan: perbaikan atas mutu mortar dan penggabungan teknologi pembuatan berbagai komposit.

Serbuk kayu penggergajian merupakan salah satu jenis partikel kayu yang bobotnya sangat ringan dalam keadaan kering dan mudah diterbangkan oleh angin. Dimana serbuk kayu itu sendiri dikenal sebagai limbah industri meubel yang banyak tertimbun dan cenderung menjadi sampah karena pemanfaatannya yang masih relatif kecil, sehingga perlu ditangani secara serius. Pemanfaatan serbuk kayu menjadi alternatif baru untuk memperoleh beton serat karbon yang diperoleh dari pembakaran limbah serbuk kayu. Hasil pembakaran limbah serbuk kayu akan menghasilkan briket arang dan arang aktif yang mengandung karbon yang juga diharapkan dapat meningkatkan dan memperbaiki sifat mekanik dan sifat fisis beton yang jauh lebih baik dari beton yang tanpa bahan tambah tetapi tidak mengurangi mutu (Yusnita, 2009).

Sementara abu ampas tebu yang merupakan abu sisa pembakaran ampas tebu (bagase) memiliki kandungan senyawa silika $\left(\mathrm{SiO}_{2}\right)$ yang juga merupakan bahan baku utama dari semen biasa (portland). Pembakaran ampas tebu (bagase) akan menghasilkan abu ampas tebu yang memiliki kandungan senyawa silika $\left(\mathrm{SiO}_{2}\right)$ yang juga merupakan bahan baku utama dari semen biasa (portland). Komposisi tersebut menguntungkan bila bahan ini digunakan sebagai bahan pengisi pada pembuatan mortar.

Sebelumnya telah diadakan penelitian pemanfaatan abu ampas tebu dalam pembuatan beton (Rismawati, 2009) dan pada pembuatan keramik (Hanafi dan Nandang, 2010). 
Dari kedua penelitian tersebut ternyata pemanfaatan abu ampas tebu sebagai bahan tambah mampu meningkatkan kekuatan sampel.

\section{METODE PENELITIAN}

Penelitian ini dilakukan dengan dua tahap yaitu:

a) Pembuatan sampel

Pada tahap ini, mortar yang dibuat adalah mortar dengan campuran hasil pembakaran serbuk kayu dan mortar dengan campuran hasil pembakaran ampas tebu, masing-masing dengan pencampuran hasil pembakaran terhadap pasir sebesar 0\%, 5\%, 10\%, 15\%, 20\%, $25 \%$. Pasir, semen dan air dicampur dengan perbandingan $2,75: 1: 0,5$. Kemudian hasil pembakaran serbuk kayu dan ampas tebu ditambahkan kedalam campuran tersebut, masing-masing dengan massa yang bervariasi, lalu diaduk dengan mixer hingga campuran menjadi homogen. Campuran dimasukkan kedalam cetakan kubus dengan ukuran $5 \mathrm{~cm} \times 5 \mathrm{~cm} \times 5 \mathrm{~cm}$ yang telah diberi pelumas dan dibiarkan selama 24 jam. Setelah mortar berumur 24 jam cetakan dibuka dan dilanjutkan dengan perendaman selama 27 hari agar terjadi proses hidrasi antara semen dengan air.

b) Pengujian sampel

Pengujian sampel dilakukan untuk mengetahui sifat mekanik dan sifat fisisnya. Adapun pengujian yang dilakukan meliputi: uji kuat tekan dan kuat tarik dilakukan menggunakan Universal Testing Machine sesuai dengan ASTM C-109, sementara densitas dan penyerapan air digunakan persamaan perbandingan massa terhadap volume.

\section{HASIL DAN PEMBAHASAN}

a) Pengujian kuat tekan dan kuat tarik

Hasil pengujian ini dapat dilihat pada Gambar 1, 2, 3 dan 4. Dari gambar 1 dan 2 terlihat bahwa kekuatan material semakin bertambah seiring dengan penambahan abu ampas tebu pada campuran mortar. Namun, peningkatan ini hanya sampai titik optimum yaitu pada mortar yang menggunakan variasi campuran abu ampas tebu sebanyak 15\% massa. Penambahan lebih lanjut jumlah abu ampas justru menurunkan kekuatan mortar. Titik terendah di dalam eksperimen yaitu pada mortar yang menggunakan variasi campuran ampas tebu sebanyak 25\% massa. Dengan demikian abu ampas tebu dengan variasi campuran $15 \%$ massa merupakan variasi campuran optimum. Jika digunakan abu ampas tebu melebihi variasi campuran tersebut maka akan menurunkan kekuatan mortar.

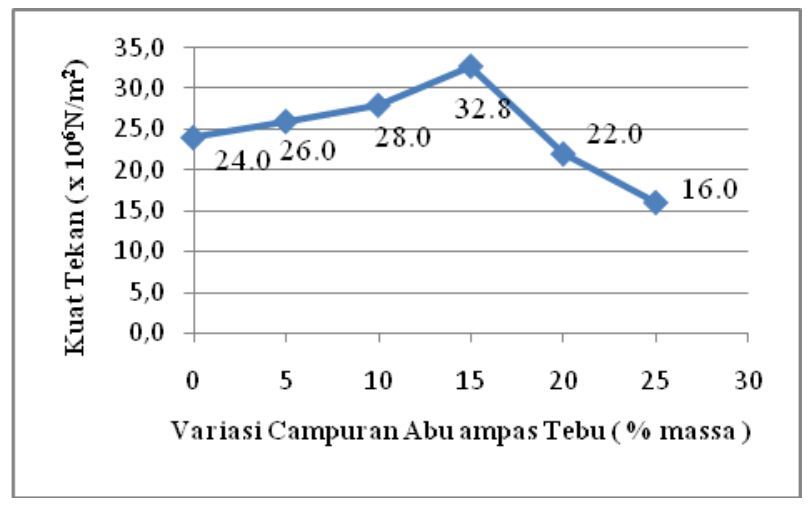

Gambar 1. Kuat tekan terhadap variasi campuran abu ampas tebu 


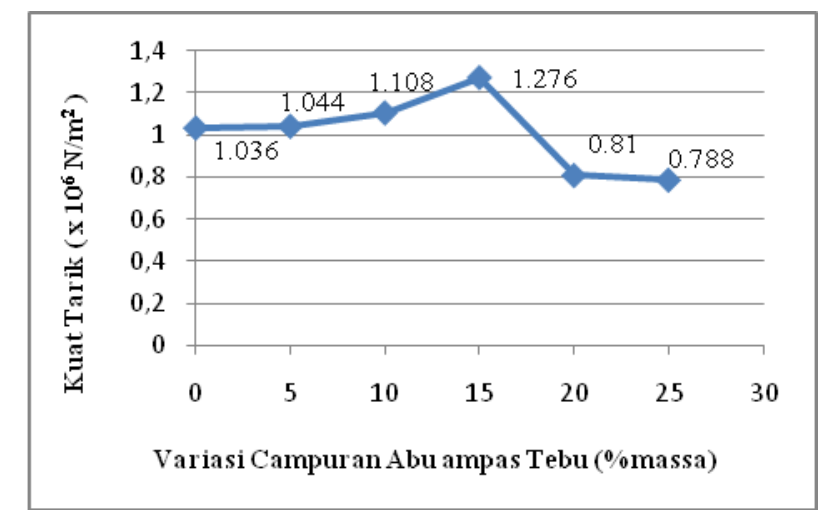

Gambar 2. Kuat tarik terhadap variasi campuran abu ampas tebu

Peningkatan kekuatan mortar ini terjadi akibat penambahan abu ampas tebu pada mortar. Dimana abu ampas tebu memiliki kandungan senyawa silika $\left(\mathrm{SiO}_{2}\right)$ yang juga merupakan bahan baku utama dari semen portland. Abu ampas tebu dapat berperan sebagai pengisi antara partikel-partikel pembentuk mortar. Dengan adanya abu ampas tebu maka porositas mortar akan menjadi lebih kecil dan selanjutnya kedapan mortar akan menjadi bertambah sehingga permeabilitas semakin kecil. Hal ini menyebabkan kekuatan mortar meningkat.

Partikel-partikel $\mathrm{SiO}_{2}$ pada abu ampas tebu yang sangat halus tersebut memiliki luas permukaan interaksi yang tinggi. Partikel-partikel tersebut berinteraksi dengan campuran pasir dan semen yang merupakan bahan baku utama dari mortar. Semakin banyak partikel yang berinteraksi, semakin kuat pula mortar. Semakin banyak ampas tebu yang dimasukkan, kekuatan dari material mortar juga bertambah sampai titik optimumnya dan kemudian turun.

Penurunan ini timbul karena penggunaan silika secara berlebihan diatas $15 \%$, akan membawa dampak negatif yaitu dengan timbulnya reaksi alkali silika. Reaksi alkali silika merupakan reaksi antara kandungan silika aktif dalam abu ampas tebu dan alkali silika dalam semen. Reaksi ini membentuk suatu gel alkali-alkali yang menyelimuti butiranbutiran agregat. Gel tersebut dikelilingi oleh pasta semen dan akibatnya terjadi pemuaian, yang dapat mengakibatkan retak atau pecahnya pasta semen sehingga mortar menjadi rapuh. (Herlina, 2005).

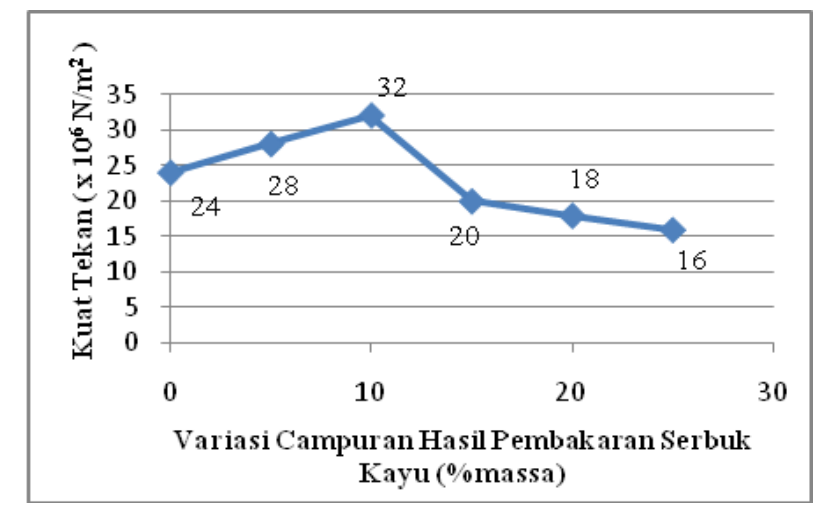

Gambar 3. Kuat tekan terhadap variasi campuran hasil pembakaran serbuk kayu 


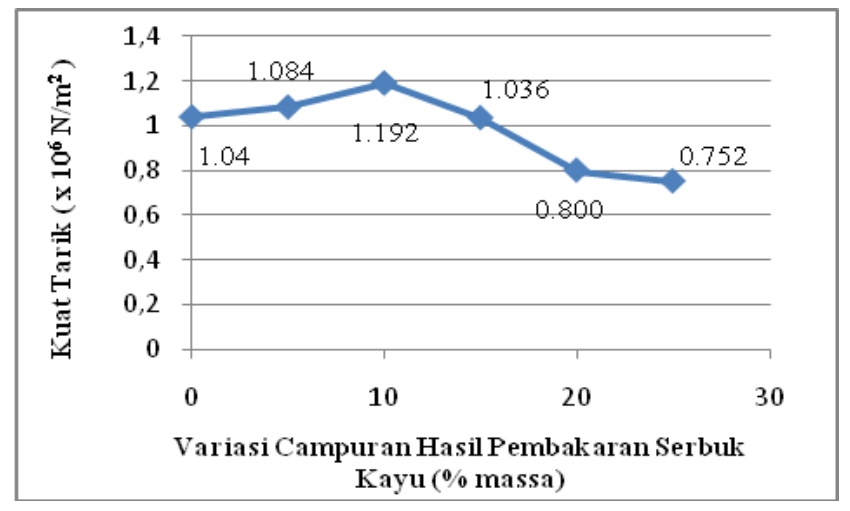

Gambar 4. Kuat tarik terhadap variasi campuran hasil pembakaran serbuk kayu

Berdasarkan Gambar 3 dan 4, kekuatan material semakin bertambah seiring dengan penambahan hasil pembakaran serbuk kayu pada campuran mortar. Namun, peningkatan ini hanya sampai titik tertentu, dimana penambahan lebih lanjut jumlah abu ampas justru menurunkan kekuatan mortar. Titik tertinggi dalam eksperimen yaitu pada mortar yang menggunakan variasi campuran ampas tebu sebanyak 10\% massa. Dan titik terendah di dalam eksperimen sebesar yaitu pada mortar yang menggunakan variasi campuran ampas tebu sebanyak 25\% massa. Dengan demikian hasil pembakaran serbuk kayu dengan variasi campuran $10 \%$ massa merupakan variasi campuran optimum. Jika digunakan abu ampas tebu melebihi variasi campuran tersebut maka akan menurunkan kekuatan mortar.

Fenomena ini dapat dijelaskan sebagai berikut. Tanpa hasil pembakaran serbuk kayu, pada mortar terdapat ruang kosong (porositas). Gaya ikat yang terbentuk hanya gaya ikat antar pasir dan semen. Dengan menambahkan sedikit hasil pembakaran serbuk kayu, partikel-partikel hasil pembakaran serbuk kayu mulai mengisi ruang kosong pada mortar. Akibatnya muncul ikatan baru yang bekerja pada mortar, yaitu ikatan antara campuran pasir dengan semen dan ikatan antara campuran pasir dengan semen dan partikel hasil pembakaran serbuk kayu.

Jika hasil pembakaran serbuk kayu ditambah lebih lanjut maka makin banyak terbentuk ikatan antara campuran pasir dengan semen dan partikel hasil pembakaran serbuk kayu sehingga kekuatan mortar makin meningkat. Jika hasil pembakaran serbuk kayu diperbanyak lagi maka mulai muncul ikatan antar hasil pembakaran serbuk kayu itu sendiri. Karena hasil pembakaran serbuk kayu mengandung banyak karbon dimana karbon merupakan grafit maka ikatan antar karbon cukup lemah, bahkan lebih lemah dari ikatan antar karbon dan mortar. Dengan demikian kehadiran ikatan antara karbon-karbon akan memperlemah kekuatan mortar. Penambahan karbon makin banyak menyebabkan jumlah ikatan antar karbon makin banyak sehingga mortar makin rapuh. (Abdullah, 2008).

\section{b) Densitas}

Penelitian dengan memvariasikan proporsi penambahan hasil pembakaran ampas tebu dari 0\% massa - 25\% massa diperoleh hasil densitas seperti yang terlihat pada Gambar 5 . Berdasarkan Gambar 5, densitas material semakin bertambah seiring dengan penambahan abu ampas tebu pada campuran mortar. Namun, peningkatan ini hanya sampai densitas tertinggi sebesar $1144 \mathrm{~kg} / \mathrm{m}^{3}$, yaitu pada mortar yang menggunakan variasi campuran ampas tebu sebanyak 15\% massa. Penambahan lebih lanjut jumlah abu ampas justru menurunkan densitas mortar. Dan densitas terendah di dalam eksperimen sebesar 1080 $\mathrm{kg} / \mathrm{m}^{3}$ yaitu pada mortar yang menggunakan variasi campuran ampas tebu sebanyak $25 \%$ massa. Dengan demikian abu ampas tebu dengan variasi campuran $15 \%$ merupakan variasi campuran optimum. 
ISSN 1979-4657

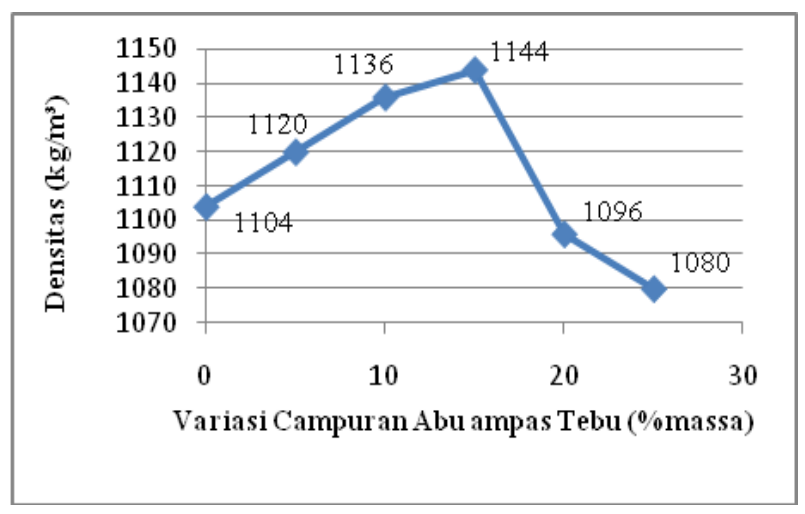

Gambar 5. Densitas terhadap variasi campuran abu ampas tebu

Densitas material semakin bertambah seiring dengan penambahan hasil pembakaran serbuk kayu pada campuran mortar (Gambar 6). Namun, peningkatan ini hanya sampai titik optimum sebesar $1140 \mathrm{gr} / \mathrm{cm}^{3}$, penambahan hasil pembakaran serbuk kayu lebih lanjut kedalam campuran mortar malah menurunkan densitas. Densitas tertinggi dalam eksperimen sebesar $1140 \mathrm{gr} / \mathrm{cm}^{3}$, yaitu pada mortar yang menggunakan variasi campuran hasil pembakaran serbuk kayu sebanyak 10\% massa. Dan densitas terendah di dalam eksperimen sebesar $1080 \mathrm{gr} / \mathrm{cm}^{3}$ yaitu pada mortar yang menggunakan variasi campuran hasil pembakaran serbuk kayu sebanyak 25\% massa. Dengan demikian hasil pembakaran serbuk kayu dengan variasi campuran $10 \%$ massa merupakan variasi campuran optimum.

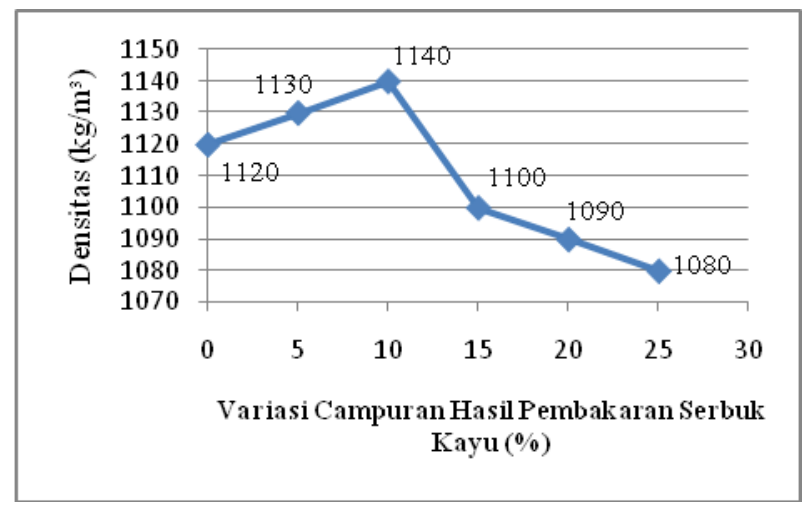

Gambar 6. Densitas terhadap variasi campuran hasil pembakaran serbuk kayu

Hal ini berhubungan erat dengan hasil uji kuat tekannya semakin tinggi kuat tekan maka densitasnya semakin tinggi dan jika kuat tekan rendah maka densitas juga rendah.

\section{c) Penyerapan Air}

Sebagaimana yang terlihat pada Gambar 7, penyerapan air mortar semakin berkurang seiring dengan penambahan abu ampas tebu pada campuran mortar. Namun, penurunan ini hanya sampai nilai penyerapan air 1,4\% dan dimana penambahan lebih lanjut jumlah abu ampas justru menaikkankan penyerapan air mortar. Penyerapan air tertinggi dalam eksperimen sebesar 2,94\% yaitu pada mortar yang menggunakan variasi campuran ampas tebu sebanyak $25 \%$ massa. Penyerapan air terendah di dalam eksperimen sebesar 1,4\% yaitu pada mortar yang menggunakan variasi campuran ampas tebu sebanyak $15 \%$ massa. 
Dengan demikian abu ampas tebu dengan variasi campuran 15\% massa merupakan variasi campuran optimum.

Pada mortar dengan campuran abu ampas tebu melebihi 15\% massa akan bersifat penyerapan air yang sangat tinggi dengan demikian kekuatan mortar akan semakin berkurang atau akan lebih mudah retak sehingga kekuatan tekan dan tariknya akan berkurang. Hal ini disebabkan karena penggunaan abu ampas tebu yang terlalu banyak akan menyebabkan mortar menjadi berongga.

Penelitian dengan memvariasikan proporsi penambahan hasil pembakaran serbuk kayu dari $0 \%$ massa - $25 \%$ massa diperoleh hasil pengujian penyerapan air dapat dilihat pada Gambar 8. Penyerapan air mortar semakin berkurang seiring dengan penambahan hasil pembakaran serbuk kayu pada campuran mortar. Namun, penurunan ini hanya sampai titik tertentu, dimana penambahan lebih lanjut jumlah hasil pembakaran serbuk kayu justru menaikkankan penyerapan air mortar. Penyerapan air tertinggi sebesar 3,7\% yaitu pada mortar yang menggunakan variasi campuran hasil pembakaran serbuk kayu sebanyak $25 \%$ massa. Sedangkan penyerapan air terendah sebesar $1,75 \%$ yaitu pada mortar yang menggunakan variasi campuran hasil pembakaran serbuk kayu sebanyak $10 \%$ massa. Dengan demikian hasil pembakaran serbuk kayu dengan variasi campuran $10 \%$ massa merupakan variasi campuran optimum.

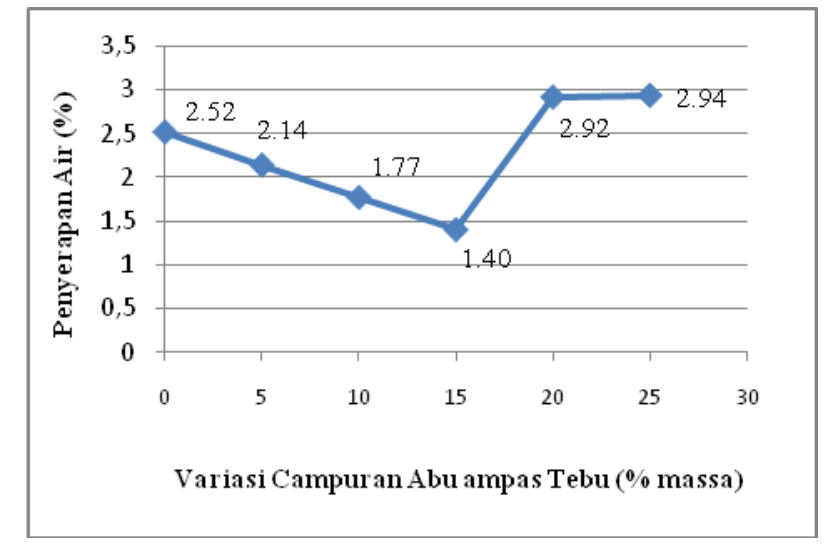

Gambar 7. Penyerapan air terhadap variasi campuran abu ampas tebu

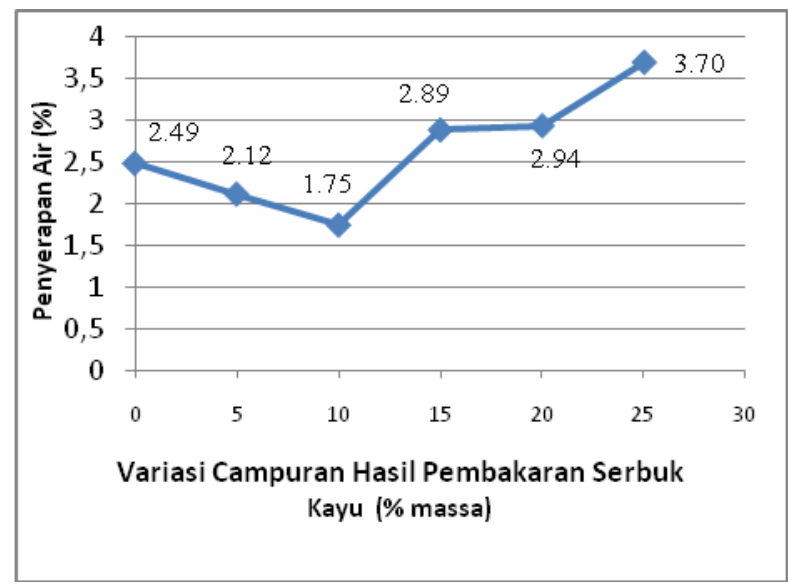

Gambar 8. Penyerapan air terhadap variasi campuran hasil pembakaran serbuk kayu 
Pada mortar dengan campuran abu ampas tebu melebihi $10 \%$ massa akan bersifat penyerapan air yang sangat tinggi dengan demikian kekuatan mortar akan semakin berkurang atau akan lebih mudah retak sehingga kekuatan tekan dan tariknya akan berkurang. Hal ini disebabkan karena penggunaan hasil pembakaran serbuk kayu yang terlalu banyak akan mengakibatkan mortar menjadi berongga.

\section{KESIMPULAN}

Dari hasil penelitian dan pembahasan yang telah dilakukan diperoleh kesimpulan adanya peningkatan kekuatan tekan, kekuatan tarik dan densitas serta penurunan porositas dan penyerapan air seiring dengan peningkatan variasi campuran abu ampas tebu dan hasil pembakaran serbuk kayu sampai dicapai hasil optimum. Hasil optimum pada pencampuran abu ampas tebu yaitu pada variasi campuran 15\% sedangkan hasil optimum pada pencampuran hasil pembakaran serbuk kayu yaitu pada variasi campuran $10 \%$.

\section{DAFTAR PUSTAKA}

1. Achmad. H. S, Nandang. A. R, 2010, Studi Pengaruh Bentuk Silika dari Abu Ampas Tebu terhadap Kekuatan Produk Keramik, Jurnal Kimia Indonesia, Vol. 5, No 1, $2010: 35-38$

2. Daryanto, 1994, Pengetahuan Tekhnik Bangunan, Penerbit Rineka Cipta, Jakarta.

3. Hadyawarman, dkk. 2008, Fabrikasi Material Nanokomposit Superkuat, Ringan dan Transparan Menggunakan Metode Simple Mixing, Jurnal Nanosains \& Nanoteknologi. Vol 1, No 1, Februari 2008: 14-21.

4. Herlina F, Silvia. Kajian Pemanfaatan Abu Sekam Padi untuk Stabilisasi Tanah dalam Sistem Pondasi di Tanah Ekspansi. Diakses tanggal 7 Januari 2009.

5. Abdullah. M, dkk, 2009, Sintesis Keramik Berbasis Komposit Clay-Karbon dan Karakterisasi Kekuatan Mekaniknya Jurnal Nanosains \& Nanoteknologi Vol. 2 No.2, Juli 2009: 83-89

6. Murdock. J. L, Brook K. M, Stephanus Hendarto,1991, Bahan dan Praktek Beton, Edisi keempat, Erlangga.

7. Pari. G, 2002, Teknologi Alternatif Pemanfaatan Limbah Industri Pengolahan Kayu, Makalah M. K. Falsafah Sains, Program Pascasarjana IPB, Bogor.

8. Rismawati, 2009, Pengaruh Penambahan Abu Ampas Tebu Terhadap Kekuatan Beton, Skripsi, Universitas Sumatera Utara, Medan.

9. Yusnita, 2009, Pengaruh konsentrasi abu serbuk kayu terhadap kuat tekan dan sifat fisis Beton, Skripsi, Universitas Sumatera Utara, Medan. 